\title{
Implementation of Tree Structure and Recursive Algorithm for Balinese Traditional Snack Recipe on Android Based Application
}

\author{
https://doi.org/10.3991/ijim.v10i4.5953 \\ A.A. Kompiang Oka Sudana, I Wayan Gede Mayun Kepakisan and Ni Kadek Dwi Rusjayanthi \\ Udayana University, Bali, Indonesia
}

\begin{abstract}
Due to the difficulty of obtaining information about the dough of Balinese traditional snack (jajanan tradisional Bali), causing Hindu community in Bali, do not know the importance of the role of traditional snack in Yadnya ceremony. Rapid technological developments that pushed for an alternative in order that information is easily obtained by making an application. Implementation of tree structure in the process of preparing an Android-based information allow users to know the material linkages with other materials. Other support such as recursive algorithm which is used to ease in calculation of the amount of materials displayed on the Application. therefore expected with this application, Hindu community in Bali will be easier to understand and find out information about the dough of Balinese traditional snack.
\end{abstract}

Index Terms-Android, Balinese Traditional Food, Recursive Algorithm, Tree Structure

\section{INTRODUCTION}

Balinese traditional snack are refined traditional snack made from crops. Offerings (Upakara) in Bali such as in Yadnya ceremony are usually not spared from Balinese traditional snack (jajanan tradisional Bali), where the meaning was contained in the form, type, as well as the materials used. Forms of Balinese traditional snack means offering natural products that exist on the Earth in the form of symbols [1]. The problem that occurs is the lack of information about Balinese traditional snack cause of Hindus in Bali would prefer to follow the globalization, by purchasing Banten to save their time and their money [2].

Communities purchased for Banten and jajanan tradisional Bali as a complement of Banten that make young people less aware about the traditions and culture have been passed down. This habit if allowed to an impact on the loss of cultural identity in Bali. Therefore, it can be made an alternative to designing system related information about the dough of Balinese traditional snack. The information system was designed to be able to touch all elements in society, especially young people as the next generation of culture that has existed.

The information system developed in this study is an Android application on the dough of Balinese traditional snack with online storage media. The purpose of this research is to build a mobile application on the Android platform with the implementation of the results into the system design applications allowing users can get information about the dough of Balinese traditional snack.

\section{RELATED WORKS}

Research conducted by Oka Sudana and Brampramana (2014), entitled "Tree Data Structure Implementation in Android Base System of E-Ulambebantenan" whereby, the design of information systems applications ulam bebantenan, which is based of mobile is an information system that would provide information about the ulam bebantenan start from types, materials, to the stage of manufacture which would later be linked with the offerings and also the type of ceremony performed [3].

Another study conducted by Asriani (2009), entitled "Rancang Bangun Sistem Informasi Menu Development pada Perusahaan Inflight Catering Service" whereby the Menu Development Information System is an information system that processes formation the menu are ordered by a customer to establish contracts menu. The processed data including; material item data, prescription data, menu data, daily uplift data, uplift standard data, SOB (Sale On Board) data, SOG (Sale on Ground) data, unit data, currency and conversion data. Also there is an additional form of formation the chart to determine the use of a material item, recipe, menu, formation a kitchen recipe, menu order per customer and produce report menu contract, as the result of an agreement of both parties during presentation menu [4].

Subsequently, research conducted by Oka Sudana, Sukarsa, Wahyu Saputra (2014), in general Yadnya ceremony requiring equipment such as the following

a) Yadnya group, describes a group ceremony.

b) The description, describes the ceremony yadnya

c) Execution time, the time or the day of the Yadnya ceremony.

d) Level of ceremony, the levels are: Uttama, Madya, Kanista.

Level of ceremony consists of pemuput, place of the ceremony, implementation procedures, the meaning of ceremony, video and pictures of the ceremony. Pemuput, place of the ceremony, implementation procedures, the meaning of ceremony, videoand pictures placed after the ceremony because the same ceremony has different levels ranging of the: Pemuput, place of the ceremony, implementation procedures, the meaning of ceremony, video and pictures of the different ceremonies [5].

Based on research conducted by Pinatih (2014), describes the population structure of the family tree and Bali customary law illustrates that technology has an important role in supporting the culture. This research 
facilitate in population census. Additional features of the system that created the information that is data management of the organization in banjar, and the dissemination of information to society with the purpose of reducing the amount of paper [6].

Whereas, this study implements the tree structure in the process of presenting the information. Android as a medium for the development of applications, provides users the ease in accessing information via smartphone. Other support such as recursive algorithm which is used to ease in calculation of the amount of materials displayed on the Application.

\section{METHODS}

Flowchart of research used as a reference in the implementation of making the application. The following is an explanation of each part of the flowchart in Figure 1.

\section{A. Observation}

Observation is a method to analyze and conduct direct recording in behavior to ensure the application created efficient and functioning properly.

\section{B. Literature Review}

Literature review is collecting data and information through sources such as books, papers, digital books, internet, and other sources associated with the object of research. The results of this literature review as reference relevant to research problems.

\section{Modeling System}

Modeling system is to design a system in the form of tree structure of a reference data which is designed into the application design.

\section{Designing of Design Applications}

Designing an application carried out to display design of an application. The importance of interactions between people and devices as a function of an application to be able to provides users the ease in getting information.

\section{E. Database Design}

The design of a database used to design a good data base in terms of server and client. Determination of valid data applied in the application, thus making the application and calculation becomes appropriate.

\section{F. Application development}

Application development is the stage in which to correct errors in the development of small errors caused by errors due to errors in the initial draft.

\section{G. Trial Application}

The trial was conducted to determine how far the application may fix the problem. Preparation of reports continued if the trial successfully. If the trials conducted have not been successful, then the stage of the enhanced return on application design.

\section{H. Making Report}

Making the report made after the test successfully. Report was created by explaining making process of an application that starts from the background of the creation of applications, creation flow, a general explanation of the application until the final outcome of the application. Thus, it can be used as reference in future studies.

\section{IMPLEMENTATION}

The dough application of jajanan tradisional Bali describes the parts of material and tools used in making snack (jajanan). Making snack(jajanan) may consist of basic materials and other snack (jajanan). There is also the explanation of the function of each snack (jajanan).

Application of recursive algorithm supports application performance. Algoritman recursively used in the calculation of his own basic materials needed by one of the snack (jajanan). Considering the recursive algorithm is a function that can call itself [7]. Thus, this application can help users in determining the amount of material used in accordance with the desire.

Figure 2 describes the assessment models that can solve the problem that is built into the system. Therefore, it is very important to pin down about the whole relationship between snack (jajanan). Thus, the tree data structure created to ease in calculation and modeling systems.

Figure 2 states that jajanan tradisional Bali has components such as Jajan Bebangkit, Jajan Suci, Jajan Pulogembal, and Jajan Saji as the example of the problems raised and applied to the system. Each of these snack (jajanan) is formed by some other snack so that snack has complex meanings.

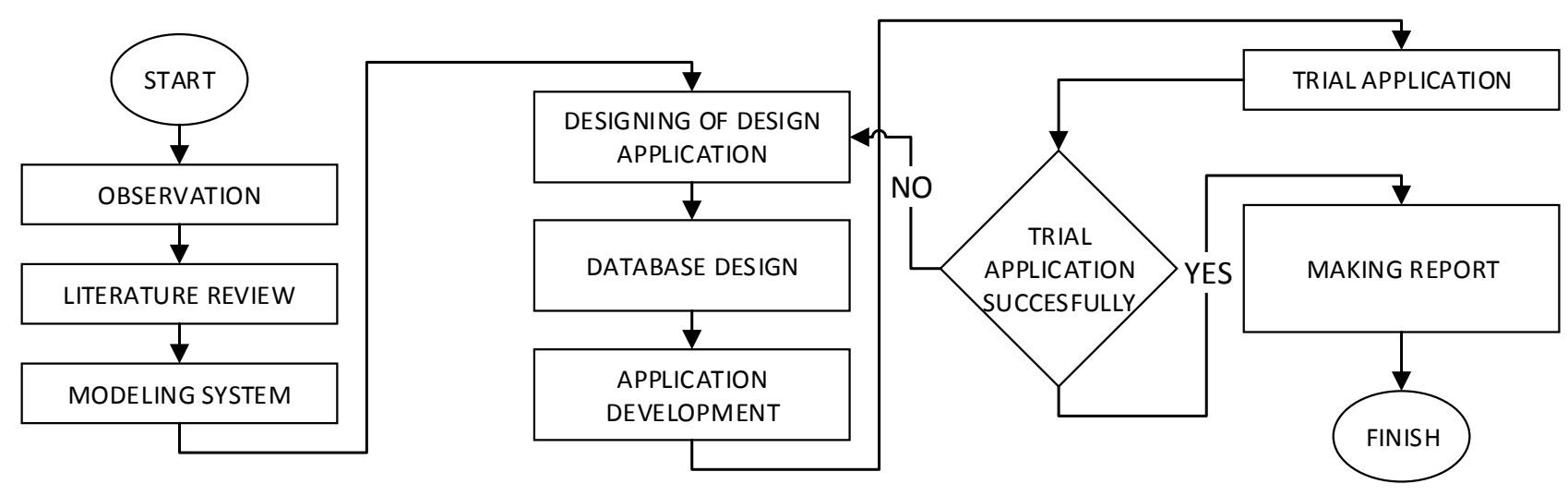

Figure 1. Flowchart a series of activities in testing system. 
PAPER

IMPLEMENTATION OF TREe Structure AND RECURSIVE AlgORITHM FOR BALINESE TraditionAl SNACK RECIPE ON...

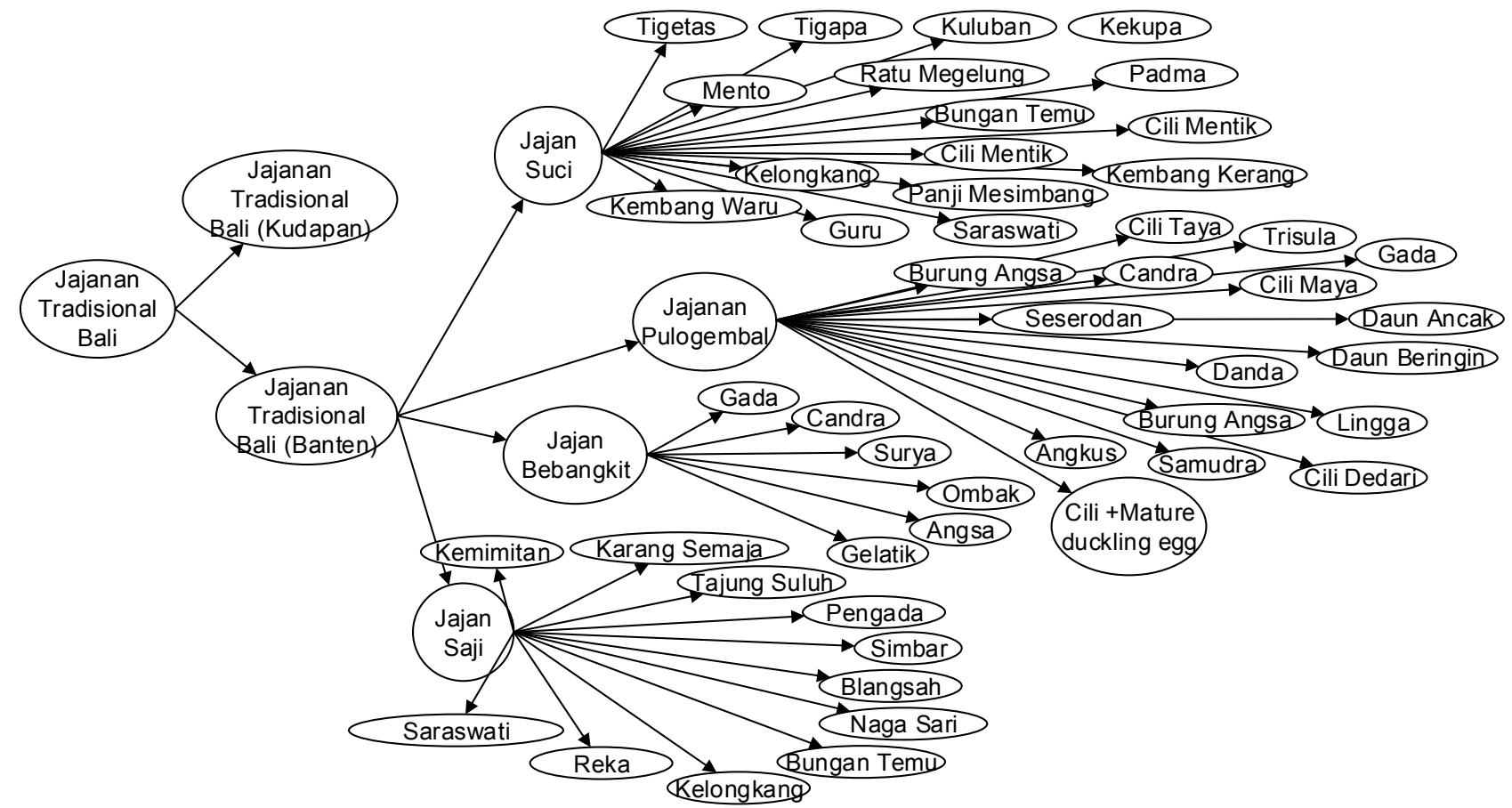

Figure 2. Tree Structure Adonan Jajanan Tradisional Bali

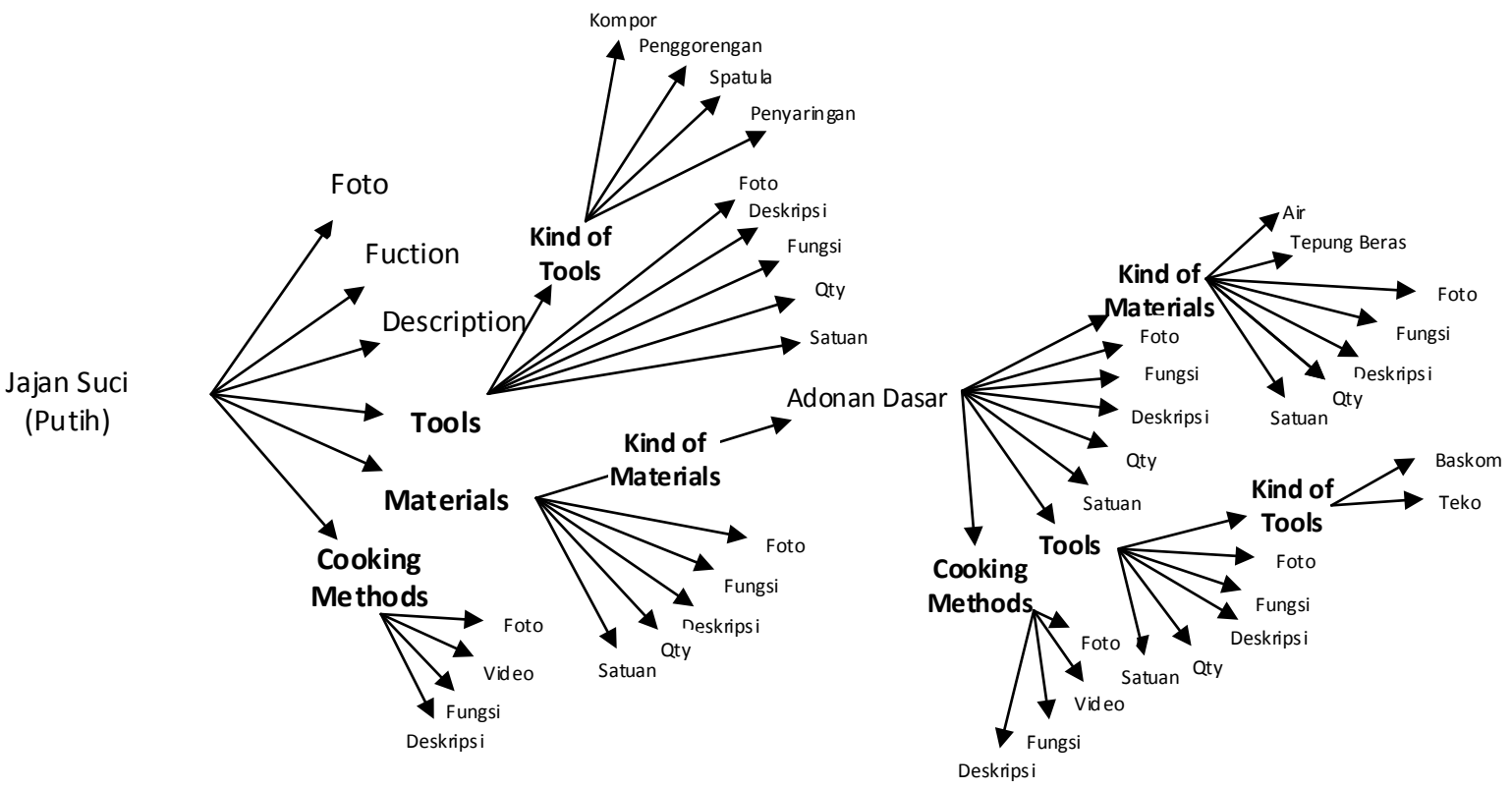

Figure 3. Tree Structure of Jajan Suci (Putih)

Jajanan tradisional Bali using the model tree structure consists of classification snack (jajanan) and components of each snack (jajanan). One example is Jajan Suci in white color as shown in Figure 3. Jajan Suci is in white color in Figure 3 consists of component information about the photos. description, function, equipment, materials, cooking methods.

After making the tree structure, obtained an application design. This application design easier for the application of product design into an application. Applications created using the Java programming language with the help of Android Studio tools. Thus, the produce applications Dough of Balinese traditional snack with Android base. Other designs are designing a database. The database was designed to be accessible online by the application. The use JSON (JavaScript Object Notation) format taking the query result from the database server and display in the Android Smartphone Device [8], thus, use it can access anytime and anywhere. Furthermore, conducted trials.

Testing processes done on Android-based smartphone with the Android version 5.0 or API Level 21. The database is stored on a server and accessed using a web service on the Smartphone with the Internet media which is connected to the Application.

Figure 4 (a) Provide information to users on a variety of snack (jajanan) contained within the system. Applications providing information of snack can be done by pressing one of the snack displayed 4 (b). 


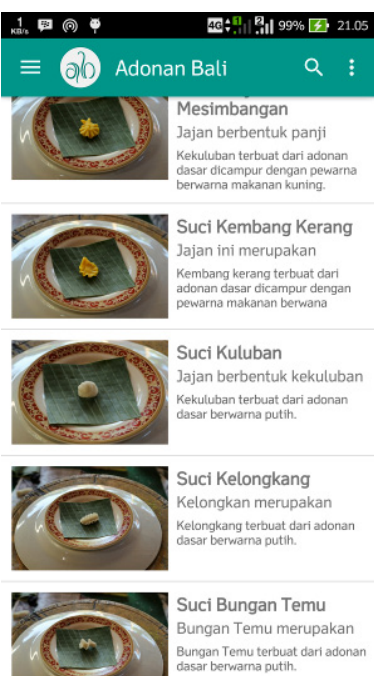

(a)

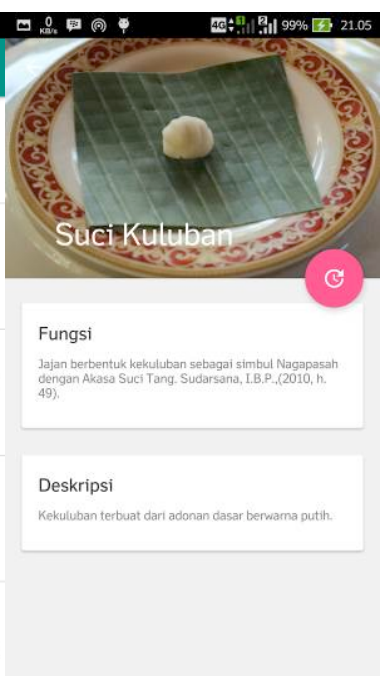

(b)
Figure 4. (a) Main menu, (b) Details item of snack menu

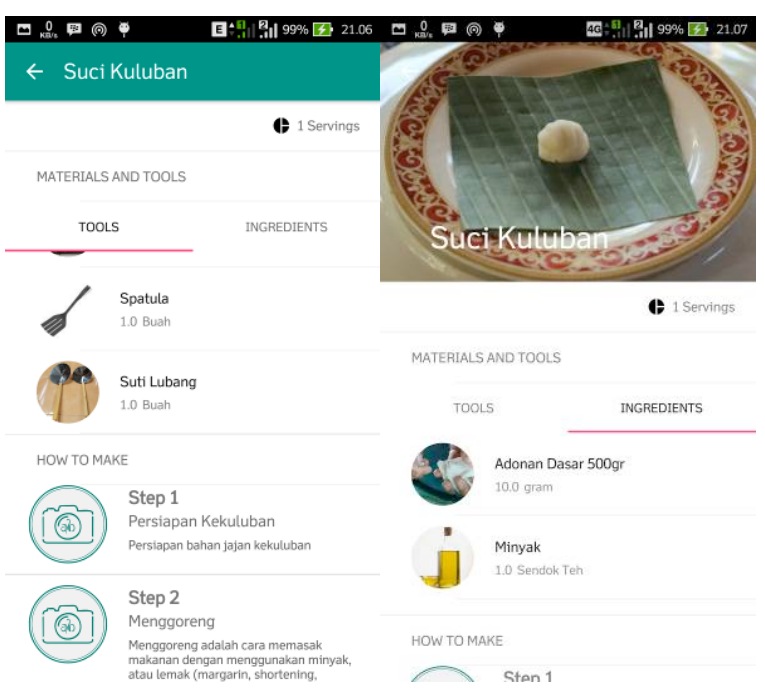

(a)

(b)

Figure 5. (a) Detail Menu about tools of Jajan Kuluban, (b) Detail Menu about ingredients of Jajan Kuluban

Ways to see the detail of the Jajan Suci Kuluban is by using a long press features of the snack (jajanan) selected.

Watch the process of making with the video features is by using a long press features, on the stage of making selected / desired.

Enhancements application with the the calculation of the basic ingredients of the Jajan Suci Kuluban using parameter values in Figure 7 (a). The presentation of recursive algorithm is implemented in this process. The way it works by throwing a piece of data which is sent by JSON format from database server through the web server into the application. Database processed on webserver using a recursive function that is created when materialtype the dough of recipe calling process itself is done continuously until the type of material. All types of the same material accumulated thus getting the desired amount of material calculation. Figure 7 (b) is the total amount of base material with the presentation 6 (six).

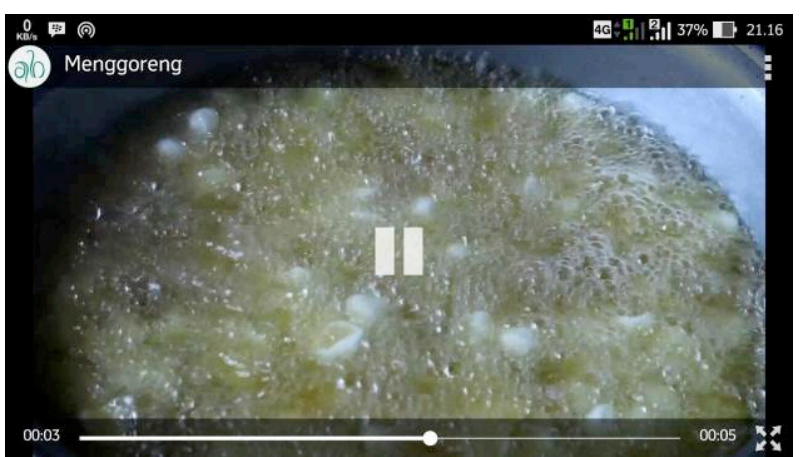

Figure 6. Video of Steps in making Jajan Kuluban

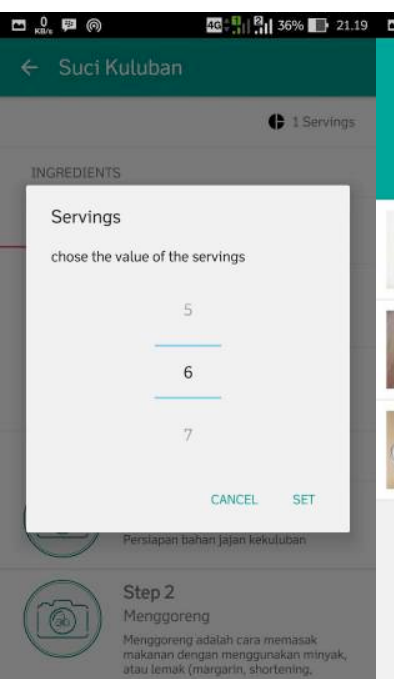

(a)
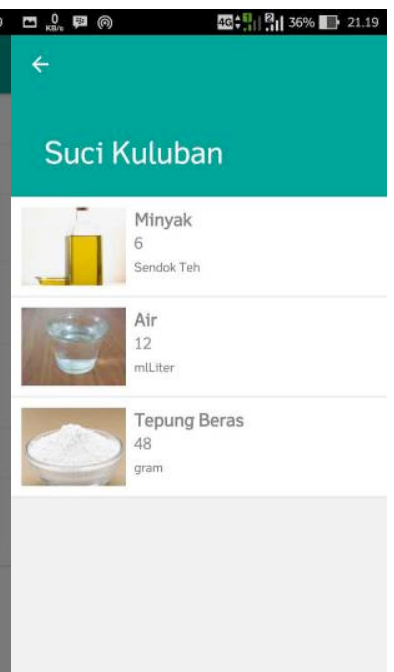

(b)
Figure 7. (a) Determination of the dishes number (b) The results of the basic material accumulation.

This application may facilitate the user to get information about the total of each basic ingredient on a recipe. Technology combined with culture can be an interesting thing to be developed. [9]. Thus, Balinese Hindu will better understand and find out information about the dough of traditional balinese snack.

\section{CONCLUSION}

The test result information systems of the dough of $j a$ janan tradisional Bali has been described in the previous discussion. It can be concluded that.

1. Jajanan tradisional Bali Information System providing information to the Hindus especially on $j a$ janan tradisional Bali.

2. Jajanan tradisional Bali Information System consists of photos, descriptions, functions, tools, materials and cooking methods in the form of video.

3. The tree structure can be used to modeling the snack category because the tree could explain some of the sub-level of snack (jajanan).

4. The application of the calculation using recursive algorithm makes it easy to settle issues such as the calculation of the amount of material used.

5. The application using online storage media, thus it can be accessed anywhere and anytime. 


\section{ACKNOWLEDGMENT}

Thank you for Udayana University who has supported the research. The entire academicians Department of Information Technology Faculty of Engineering, Udayana University.

\section{REFERENCES}

[1] Sudarsana, I.B.P, "Himpunan Tetandingan Upakara Yadnya", Yayasan Dharma Acarya, 2010.

[2] Widana, I.G.K, "Banten Siap Saji Pentas Konsumerisme di Panggung Ritual”, Pustaka Bali Pos, 2015.

[3] Oka Sudana, Brampramana Putra, "Tree Data Structure Implementation in Android Base-System of E-Ulambebantenan", Trans Techpublications. Switzerland, Vol.776 pp. 431-436, 2015.

[4] Asriani, Ni Nyoman, "Rancang Bangun Sistem Informasi pada Perusahaan Inflight Catering Service Studi Kasus PT. Jasapura Angkasa Boga", unpublished.

[5] Oka Sudana, A.A.K., Sukarsa, I Made and Wahyu Saputra, I Made, "Information System of Yadnya Ceremony on AndroidBased", International Journal of Hybrid Information Technology, Vol.7 No.6 pp. 155-164, 2014. http://dx.doi.org/10.14257/ ijhit.2014.7.6.13

[6] I Gusti Bagus Ari Pinatih, A.A. Kompiang Oka Sudana, I Ketut Adi Purnawan, "E-Banjar Bali, Population Cencus Management Information System of Banjar in Bali by Using Family Tree Methode and Balinese Culture Law", Journal of Theoretical and Applied Information Technology, Vol.59 No.2 pp.411-420, 2014.

[7] Song Jinping, "Discussion on Writing of Recursive Algorithm", International Journal of Hybrid Information Technology, Vol.6, No.6, pp.127-134, 2013. http://dx.doi.org/10.14257/ijhit.2013. $\underline{6.6 .11}$

[8] Dunlu PENG, Lindo CAO, and Wenjie XU, "Using JSON for Data Exchanging in Web Service Application", Journal of Computation Information System Vol.7 No.16 pp. 5883-5890, 2011.

[9] A.A. Kompiang Oka Sudana, I Ketut Adi Purnawan and Ni Made Riana Mahlia Dewi, "Android Based Translator of Balinese into Indonesian using Binary Search Method", International Journal of Software Engineering and Its Applications

\section{AUTHORS}

A.A.Kompiang Oka Sudana is currently lecturer at Magisterial Program of Electrical Engineering Department of Udayana University, lecturer at Electrical Engineering Department (major in Computer System and Informatics) of Udayana University, lecturer at Information Technology Department of Udayana University. He received his S.Kom degree in Informatics Engineering from Institut Teknologi Sepuluh Nopember University in 1997, and his M.T. degree in Informatics and Computer System from Gadjah Mada University in 2001. His research experiences were in Analysis and Design of Information Systems, Image Processing, Biometric Identification and Recognition, Implementation Information Technology in Balinese Culture. (e-mail: agungokas@unud.ac.id).

I Wayan Gede Mayun Kepakisan studies in the department of Information Technology, Udayana University, Bali, Indonesia. His research experience was in combining culture and technology also analyzing and designing an information system based on Android. He graduated his S.TI. at the Information Technology Department from Udayana University on 2016. (e-mail: mayoeen_kps@hotmail.com).

Ni Kadek Dwi Rusjayanthi is currently a lecturer at the Information Technology Department of Udayana University and specialize in Expert Systems, Data Mining, Soft Computing and Algorithms. She was received her S.T. degree in Informatics and Computer Systems Program of Electrical Engineering Department from Udayana University in 2008, and her M.T. degree in Management Information Systems and Computer Program of Electrical Engineering Department Department from Udayana University in 2012. (e-mail: dwi.rusjayanthi@unud.ac.id).

Submitted, 18 June 2016. Published as resubmitted by the authors on 09 August 2016. 